\title{
Chapter 15. People and Place in Tonga: The Social Construction of Fonua in Oceania
}

\section{Steve Francis}

Every Tongan adult has both a fonua, or island/village identity, and a famili/kainga, or kin set identity. (G. Marcus 1975: 37)

\section{Introduction}

\section{Local Territory and Global Identity}

This paper seeks to explore the social classification and territorial concept of fonua in the Pacific Island Kingdom of Tonga. A reflex of the reconstructed Proto-Austronesian territorial category *banua, the word fonua as it is utilised in Tonga intimately connects the people of Tonga with the places that represent Tonga. ${ }^{1}$ Fonua therefore constructs people and place as a bonded entity.

Although Tonga has been a Christian nation for more than a century, fonua invokes for Tongans an indigenous cosmology in which the environment is regarded as 'an extension of human society' (Mahina 1992: 57). As a result, human agency is integral to a physical landscape that includes the land, the ocean and the sky. In pre-constitution Tonga, the concept of fonua 'people of/and place' described a local territorial entity that incorporated the land and natural surrounds associated with a chiefly titleholding, and the people residing on that land. ${ }^{2}$ For the residents of this territory, the outcomes of association with this bounded entity included participation in communal modes of agricultural production, intimate kinship connections, and subsumption within a chiefly titleholding hierarchy, which demanded surplus production as tribute.

Disassociated from this earlier societal framework, fonua is today employed in a national/political context. In contemporary Tonga, fonua embodies notions of Tongan nationhood and positive self-identification. By contrasting positive Tongan values with negative Western values, Tongans use the word fonua to denote a connection between the place(s) and people of Tonga, wherever and whoever they might be. While the contemporary version of fonua thus embodies a new formulation, it also continues to resonate with earlier meanings.

Fonua is therefore the embodiment of both local territorial belonging (a historicised rendering) and national self-identification (a contemporary rendering), simultaneously connecting Tongans to a mythological past and linking them with a globalised present. The category therefore conflates the 
physical and the metaphysical, the historical and the mythological, the political and the social, the local and the global.

Fonua, as a conjuncture of 'people and place', underpins primary social, economic and political relationships in Tonga. Accordingly, this paper will analyse how the people of Tonga employ this social category in varying political, economic and social contexts: political, in the sense of elite-commoner relations; economic, in the context of land use and landownership; and social, within the framework of village, island, regional and national identities. The paper will seek to make explicit the multiple roles of fonua in Tonga through an examination of myth, history, social relations and local boundaries within the Kingdom of Tonga.

\section{Arrival: Austronesian-Speaking Peoples in Tonga}

Incorporated within the final expansion of the Lapita pottery-making peoples into the South-West Pacific, the first human habitation of the Tonga Group has been recently dated at between $2850 \mathrm{BP}(900 \mathrm{BC})$ and $2800 \mathrm{BP}(850 \mathrm{BC})$ (Burley, Nelson et al. 1999: 63). ${ }^{3}$ According to the evidence collected to date, the Lapita Period in Tonga conformed to many of the characteristics associated with the so-called Lapita 'cultural complex'. Archaeologists (Golson 1961; Green 1979) and anthropologists have identified a range of practices including characteristic agricultural techniques, coastal settlement and subsistence economies, which included reef and lagoon fishing and animal husbandry (pigs and fowl).

Linguistic analysis has also identified the languages spoken by the Lapita people as a subgroup of Oceanic (OC), itself a subgrouping of the major Malayo-Polynesian (MP) branch which derives from Proto-Austronesian (Blust 1980: 11). Proto-Polynesian (PN) is a further subdivision of Oceanic from which derives Proto-Tongic and Proto-Nuclear Polynesian (Kirch 1988:5; Pawley and Ross 1993: 440). The Tongan and Niuean languages have been identified as derivatives of Proto-Tongic (Kirch 1988: 5). Based on these linguistic conjectures, Blust has suggested that Tonga 'was the first (Proto-Polynesian) PN island group to be settled (by at least the late second millennium BC) and that Samoa was probably peopled from Tonga (by about 700-600 BC) in the second major PN movement' (Blust 1980: 27). ${ }^{4}$

\section{The Tongan Island Group: A Local Geography}

Centrally located in the Pacific Ocean, west of the International Dateline, south of Samoa and south east of Fiji, the Tonga Group is made up of more than 170 islands (only 43 of which are currently settled) extending in a north-south island chain. Covering a linear distance of 800 kilometres, the land area of 750 square kilometres contrasts with a claim to more than 362,500 square kilometres of ocean area (Maude 1965). 
La Perouse first pointed out that

[o]f the hundred and fifty islands which compose this archipelago, the greater number consists only of uninhabited and uninhabitable rocks. (La Perouse 1799: 173)

This rather harsh assessment notwithstanding, Tongans distinguish between four island 'clusters' within the kingdom, each with their own distinctive physical features and social normative attributes. These are the Tongatapu cluster incorporating Tongatapu and 'Eua, the dispersed Ha'apai cluster, the mountainous Vava'u cluster and the remote 'Niuas' (Niuafo'ou, Niuatoputapu and Taufahi) situated 400 kilometres north of Vava'u, physically closer to Samoa, Fiji, 'Uvea (Wallis) and Futuna than to Tonga. The inhabitants of each cluster are also ascribed idiosyncratic normative attributes by other Tongans and the residents themselves. These include stereotyping of personal characteristics, mannerisms and habits and accent differentiation as well as the assignment of social, economic and political status.

\section{Fonua in Tongan Cosmology}

On the island there is hardly any mountain, spring, or large rock that does not refer to a myth. Between space and mythology, places and culture, the symbiosis is complete (Bonnemaison 1994: 113)

The concept of fonua 'people of/and place' was located centrally in the construction and organisation of the Tongan cosmological universe. In order to investigate fonua in the context of this mythological past, the discussion will focus on two examples of mythic storytelling. Cultural forms such as poetry, dance and mythic tales provide useful insights into the order and logic of the pre-contact cosmology. The first is an excerpt from the Lau Langi, 'The Skies', a version of the ancient Tongan dance form known as the 'Otuhaka. The dance was performed for the Tu'i Tonga (the divine Kings of ancient Tonga) on ritual occasions. The second example utilised is a selection from the Tongan creation myth cycle, the Talatupu'a.

\section{Lau Langi, 'The Skies'}

Ke fanongo mai ho'o pulotu na,

Kae fai 'emau talatupu'a,

Ko e talanoa talu mei $m u^{\prime} a$,

Mei he'etau 'uluaki matua'a,

$N a^{\prime} e$ fakatapu hotau fonua,

'o fakapulonga mei 'olunga,
Listen to us you composers

Listen to us you composers

While we tell you a tale from long ago

The story from the beginning

From our first old men

Our people/place was created ${ }^{\mathrm{a}}$ 
a In the translation, Kaeppler glosses fonua as 'land', however, I have replaced it with the gloss 'people/place' in order to maintain consistency of meaning in the context of this paper.

b This extract is taken from Kaeppler (1993: 64-5).

While the primary dance forms of contemporary Tonga, such as the lakalaka, begin with a fakatapu, 'sacred salutation', which pays respect to God, the King and his nobles, pre-Christian forms began with references to the creation of the world by the pantheon of Tongan gods. The Lau Langi is no exception as it proceeds to tell the story of the creation of the atmosphere, the sunset, the air and the stars.

The opening lines of the dance are particularly interesting in the context of the present discussion as they reflect the concept of fonua in the employment of images that intimately associate people with earth, with land, with place. The use of the word 'unga, for example, is particularly evocative as it denotes a large form of hermit crab, which burrows into the ground at night. The association of crabs with the water is also emblematic of the importance of the ocean in the mythic imagination of the Austronesian people in Tonga and in the concept of fonua itself. 5

Depicting the general populace (the $t u^{\prime} a$, 'commoners') as tied to place or bound to place (i.e. a metaphor for low ranking) while associating the hou'eiki 'chiefs', with the sky (which is a metaphor for high rank) was a common practice. This was not surprising given that dance, poetry and myth-telling in general were written and performed with an 'eiki, 'chiefly', audience in mind. As a result, emphasis was placed on symbolically reinforcing the longevity and strength of the existing hierarchical order of Tongan society in poetic form.

This symbolic separation was continued, even in the afterlife. For while the 'eiki 'chiefs', were deemed to have souls, travelling to the Tongan paradise world of Pulotu upon death, the $t u^{\prime} a$, 'commoners', without souls, were deemed unfit to enter Pulotu. In fact, they were designated as the kau kaifonua , 'the people who eat place'. 6 This term, applied to commoners by the chiefs, starkly illustrates the connection made between the place and people of Tonga. In some versions of the story, the $t u^{\prime} a$, 'commoners', ended their time by travelling to the lalofonua , 'the place below' (see Gordon 1988: 25).

\section{The Talatupu'a: A Story of the Past}

In the beginning there existed only Vahanoa, 'the endless open sea', and Pulotu, 'the home of the spirits and gods'. On the surface of Vahanoa drifted Seaweed (Limu) and Earth (Kele). But they were soon separated and between them emerged a huge rock, Touia-'o-Futuna. The rock shook 
angrily causing a series of tremors, which split open Touia-'o-Futuna and from it emerged four pairs of twins, male and female, Piki and his twin sister Kele, 'Atungaki and his twin sister Ma'imoa'alongona, Fonua'uta and his twin sister Fonua'vai, and Hemoana and his twin sister Lupe. Incestuous sexual relations between each pair of twins resulted in a number of children. Taufulifonua and Havealolofonua, were the son and daughter respectively of Piki and Kele, while Hemoana and Lupe who produced a boy, Tokilangafonua and a girl, Hinatu'aifanga. ${ }^{7}$

In time Taufulifonua and Havealolofonua (brother and sister) produced a child, the Tongan goddess, Havea Hikule'o. They decided to create an island for her, called Tongamama'o (Distant Tonga). Taufulifonua then copulated with his cousin Velelahi producing the Tongan god, Tangaloa 'Eiki. He then coupled with another cousin, Velesi'i, producing another Tongan god, Maui Motu'a. When Taufulifonua was close to death, he set about dividing the universe among his children. Tangaloa 'Eiki was given Langi (the sky), Maui Motu'a was given the domain of Maama (the underworld) and Havea Hikule'o was given Pulotu, the world of the spirits, gods and demigods. ${ }^{8}$

As the island of 'Ata was still without vegetation, Tangaloa 'Eiki told one of his sons, Tangaloa 'Atulongolongo, to fly over (in the form of a kiu 'plover') and drop a seed. Eventually, a creeper covered the whole island and on returning Tangaloa 'Atulongolongo pecked a rotten branch out of which a huge worm crawled. He then pecked the worm into two pieces as instructed by his father. From the head of the worm, a man called Kohai 'Who', was formed. From the tail was formed a man called Koau, 'It is I'. A little piece was left over and this too became a man, Momo, 'fragment'. 9

The Talatupu'a, meaning 'telling of the ancient/remote past', is a cycle of myths relating to the origin and creation of the Tongan world and its people by the gods. ${ }^{10}$ It is similar to most Tongan (and other Polynesian) myths in that a basic story provides the framework on which, depending on the situation, occasion, audience, store of knowledge, locality, and politics of the event, the storyteller would add or subtract subplots or side stories. Although a mythic tale, the Talatupu'a is also a sociopolitical allegory in that it presents an ontologically ordered, Tonga-centred, elite-focused cosmogony. ${ }^{11}$ As Mahina notes, the Talatupu'a

may be regarded as a cosmic representation of the social arrangement, where the environment is seen as merely an extension of human society. It follows that, as far as the Talatupu'a is concerned, the origin of the universe is socially connected. ... Literally, the universe is thus made 
social- and environmental-specific to the Tongan social world, and the universe, at least for the Tongans, is symbolically Tongan society. (Mahina 1992: 57-8)

In the Talatupu'a, as in the Lau Langi, fonua imagery underpins the connection of environment and place with people. According to the myth, the god Tangaloa 'Atulongolongo (in the form of a bird) pecked the first humans (depicted in the story as worms) out of a rotten creeper branch. This correlation with worms, who are literally dwellers in the earth, also recalls the designation of $t u^{\prime} a$, 'commoners', as kau kaifonua, 'the people who eat place'. The association of worms and earth is further enhanced by reference to the rotten creeper branch, which brings with it images of deterioration and decay, but also of growth as the process of decomposition, facilitated by the worms, enriches the earth and promotes further growth. Again, these images recall the reference to crabs in the 'Otuhaka discussed above.

These associations are also reflected in ancient agricultural terminology. For example, Tongans use the word fonua as a descriptive term for the soil that grips the roots of plants when pulled from the earth. Images of commoners in association with the earth are also employed in concepts of life and death. The old Tongan word for the placenta (an obvious symbol of birth) is fonua. According to ancient practice, the fonua was buried after birth. As Mahina has pointed out, 'according to the Tongan worldview, people are themselves the land' (Mahina 1992: 2). Similarly, the word for grave is a derivation of fonua. In Tongan, a grave is a fonualoto, which means literally 'centre or heart of place'. Death and burial are therefore symbolically linked with a return to the place from which the worm-like kaifonua first emerged.

\section{Ocean and Sky}

In the Talatupu'a myth, the fonua is intimately connected with the ocean and the sky. At the beginning of the tale, Kele (lit: 'earth/dirt') is found drifting in the ocean. Floating like the islands of Tonga, Kele connects the ocean (tahi, 'sea', or moana, 'deep sea') with fonua. The names of the gods in the story also reflect this theme. For example, Fonua'vai, 'place/people of the water', contrasts with Fonua'uta, 'place/people of the land'.

Intimate associations of fonua and the sky are also apparent in the story. While the apical gods are literally ejaculated from the lalofonua, 'the place below', by the volcanic fury of Touia-'o-Futuna, the creation of man is precipitated by a bird dropping a seed from the sky (Tangaloa 'Atulongolongo, son of Tangaloa 'Eiki, God of the Sky) (compare with Banda origin myths, cf. Winn, this volume). The names of the gods again reflect the subtext of the tale as ocean and sky are associated with the creation of the fonua, 'people of/and place'. In the story, Hemoana (lit: 'the ocean') and Lupe ('dove', i.e. a creature of the sky) produced 
a child named Tokilangafonua. The name of the god itself tells the story of creation of the fonua by the sky and the ocean. The name may be interpreted to mean 'newly created or newly built fonua'. The construction analogy (introduced by the word langa, 'build') is further enhanced through the double meaning of the word toki, which also means 'axe/adze'.

\section{Fonua in Place: Connection and Separation}

\section{Tangaloa tu'u hake e Maui,} Ke fanongoongo hono 'otu muli

\section{Katoa Tonga ni fakatefuli}

Tangaloa, arise Maui, Harken his chain of foreign/exotic islands,

All this place of Tonga ${ }^{a}$

a This is an excerpt from the Poem of Tuku'aho (Collocott 1928: 95) written in the early 1800s by Teukava, a chief of Hihifo, Tongatapu, who was an ally of the famous Ha'apai chief, Finau Ulukalala II, whose exploits were documented by the shipwrecked seaman William Mariner in his Account of the Natives of the Tonga Islands in the South Pacific.

The juxtaposition of earth, environment, ocean and sky in the stories examined above are reflective of Tongan notions of connection and separation. These epistemological precepts continue to inform contemporary ideas about the 'people/place' complex of the fonua and Tongan ideas of place-in-the-world. As can be demonstrated through an analysis of the Poem of Tuku'aho above, notions of connection and separation are essential in connecting Tongans to place and to each other.

Written in the early 1800s, the opening lines of the poem are an invocation by the poet to Tangaloa 'Eiki, God of the Sky, and Maui Motu'a, God of the Earth, Land and Underworld. This initial section of the poem captures a sense of Tonga as a physical sequence of linked islands and as a unified social 'whole'. The sequential use of the words 'otu 'series, chain, row of islands', and muli, 'foreign', in the second line of the poem emphasises connection ('otu) and separation (muli). There are two primary agents central to the connection/association motif contained in the word 'otu - the ocean (lotomoana) and the land $(u t a){ }^{12}$

As a source of sustenance, commerce, trade, decorative objects, sacred artefacts, spouses and, of course, as the agent that enabled travel over large distances, the life-giving and life-taking aspects of the ocean have been mythologised and incorporated into a lexicon of tradition and aspects of everyday life in Tonga (and other Pacific Islands) for many millennia (see, for example, Davidson 1977; Dickinson et al. 1996; Finney 1997; Goodenough and Thomas 1989; Green and Kirch 1997; Kaeppler 1978; Weisler and Woodhead 1995). It is the ocean, the Pacific Ocean, which creates a physical 'connection' between the islands of the Kingdom and to other islands of the Pacific. Of course, it is also 
the people of Tonga who create social 'connections' across the islands of the kingdom through kinship ties, religion and their associations with place and people (via fonua).

The connection theme associated with 'otu contrasts strongly with the word muli, a separation/division motif that highlights the physical division of one island from another within the chain, as well as the distinct fonua identities of people and place associated with each Tongan island. These differences have in turn been enhanced and accentuated through myth, poetry and legend. The word muli as utilised in pre-contact times referred to Samoans, Fijians and people from other Pacific Islands such as 'Uvea, Futuna, Rotuma and Niue who lived in Tonga or with whom the Tongans had contact (Cummins 1977: 68). With the arrival of Europeans, the emphasis changed and today the word is often used to distinguish Tongans from Westerners in general, who are kau muli, 'foreigners'.

The third line concludes the introductory section of the poem with a pronouncement of unity as all the 'foreign' islands of the group are bestowed a collective identity and named 'Tonga'. The use of the word katoa, 'everything, whole, without exception', signals the all-inclusive intent (and hope) of the poet.

As will be demonstrated in the next sections, national discourse in Tonga today reflects the symbolism associated with these connection and separation motifs. In everyday speech, Tonga is referred to as a unified whole when comparing and contrasting Tonga with the rest of the palangi or 'Western' world, or with the other islands of Oceania. The separation motif also comes into play when Tongans discuss Tonga among themselves. At this point, local village and island identities will come to the fore.

Separation is also an issue for national identity in relation to the Tongan diaspora. As the dispersion and movement of the Tongan population has expanded in the contemporary era, separation and connection have become larger issues to do with cultural and ethnic identity, and thus have come to play a part in a larger debate between Tongans in Tonga and overseas (muli).

Having examined fonua as a manifestation of the mythological past, discussion now needs to move to an investigation of fonua as the principal local territorial division of pre-constitution (i.e. before 1875) Tonga.

\section{Fonua in Tongan History}

Cultures are never static: they evolve through history. That is why the process of cultural reproduction is, in part, a process of cultural transformation. At any given time a group will inherit certain cultural institutions and traditions, but its acts of reiteration or repudiation, its 
everyday interactions and its ritual practices will serve to select, modify, and transform these institutions. (Brah 1996: 18)

\section{Locality and Lineage in Pre-constitution Tonga}

In the context of pre-constitution Tonga, all land was held notionally by the Tu'i Tonga. The paramount spiritual ruler of the Tongan archipelago, the Tu'i Tonga traced direct patrilineal descent from the semi-divine 'Aho'eitu, 'day-has-dawned', the son of Tangaloa"

'Eitumatapua, a god of the sky, and Ilaheva, a woman from Niuatoputapu also known as Va'epopua (Gifford 1924: 26). ${ }^{13}$ In practice, custodianship of the land was vested in a large group of high-ranking titleholders controlling hereditary tracts as landlords rather than rulers (Maude 1971). The term used to describe these hereditary tracts and the people living on them was fonua.

Within each landholding, the populace tended towards dispersed settlement in local homesteads known as 'api. Similar in composition to the 'api of contemporary Tonga, these 'api 'homesteads' or 'houses', often consisted of a parental couple, their married children and their families, unmarried children and wider kin. The oldest male member of the 'api was known as the 'ulu or 'head' (see Figure 1 below).

Several 'api linked by patrilineal descent from a commonly acknowledged ancestor formed a fa'ahinga, 'kin group' (Gailey 1987; Grijp 1993; Maude 1965, 1971). ${ }^{14}$ Each fa'ahinga was headed by a senior-ranking male, the 'ulumotu'a or 'elder head'. ${ }^{15}$ The 'ulumotu'a often retained a minor title such as matapule, 'talking chief'. ${ }^{16}$ Several fa'ahinga on a hereditary tract of land formed a corporate kin group called the kainga, 'kindred'. ${ }^{17}$ The kainga was headed by an 'eiki si'i or 'minor chief' related to the hereditary titleholder (who was the 'eiki or $T u^{\prime} i$ 'senior chief') (see Figure 1 below). In most cases, these chiefs were younger brothers or sons of the titleholders (Bott 1982: 68-9).

In many cases, the hereditary chiefly titleholders were absentee landlords based primarily in the ancient capital of $\mathrm{Mu}^{\prime}$ a on the island of Tongatapu. As a result, chiefly titleholders often devolved everyday charge of their lands to associated patrilineal kin. In most cases, younger brothers or parallel cousins of the original titleholders, these patrilineal kin were often awarded titles of their own, known as foha, 'son', or tehina, 'younger brother', titles (Bott 1982: 68-9). These minor chiefs ('eiki si'i) were designated as tauhifonua or 'keepers or guardians of the land/people' or motu'a tauhifonua, 'the old one who looks after the land/people'. While only junior titleholders, the tauhifonua were still regarded as 'eiki or 'chiefly'. 18 
Figure 1: Territorial/social divisions of fonua

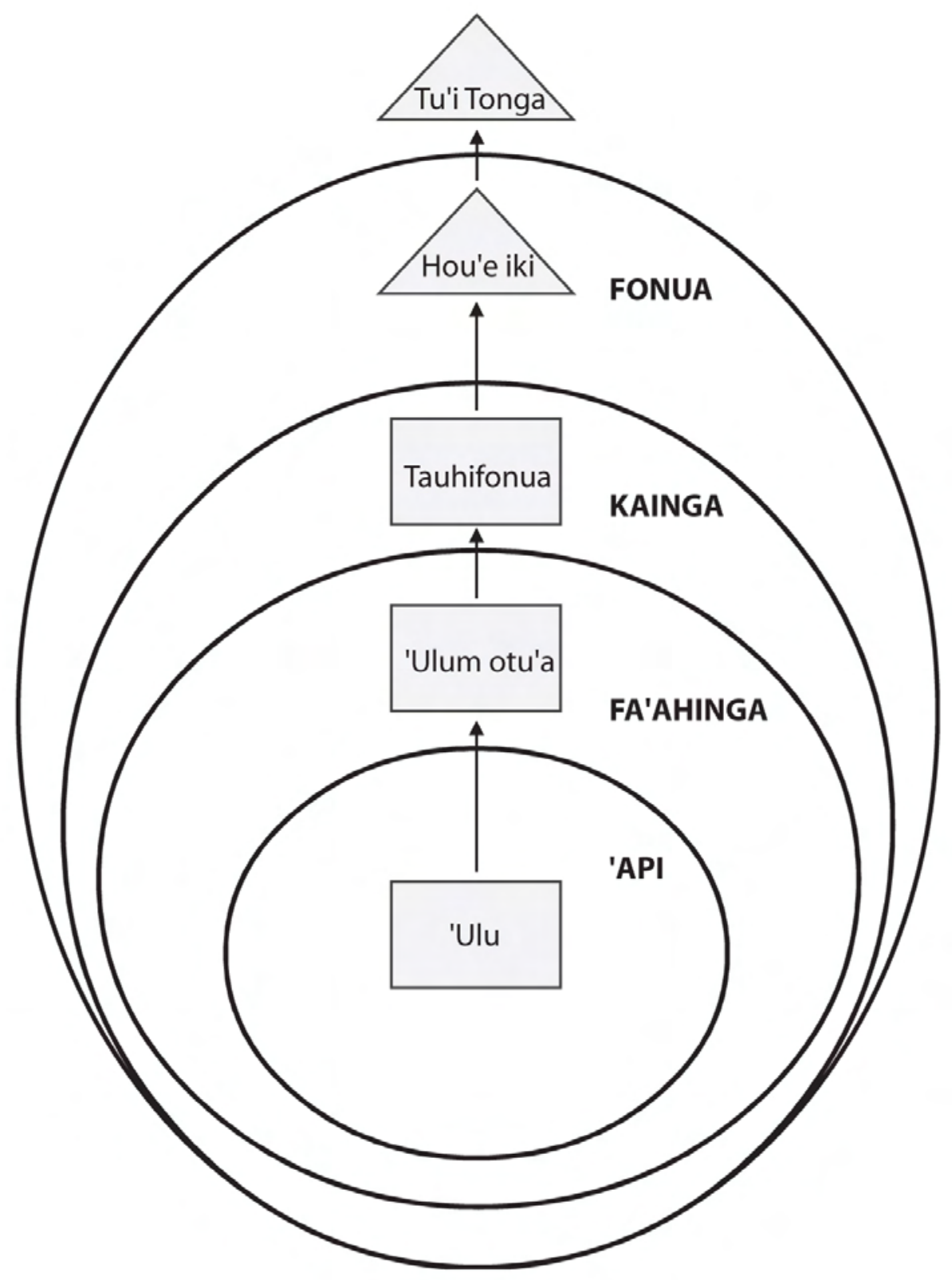

Guardians of the People/Place: Tauhifonua and Matapule The role of the tauhifonua as the keeper or guardian of the fonua or 'people and place' in the absence of the titleholder is little discussed in the literature. In fact, many writers have conflated the role of tauhifonua with that of the matapule, 
'talking chief'. A key difference between these positions is that while, as previously noted, the tauhifonua were most often connected patrilineally to the chiefly titleholder, and therefore 'eiki or 'chiefly' themselves, the hereditary matapule occupied a ceremonial non-chiefly role. As a result, in the absence of the titleholder, for example, the tauhifonua would take the 'eiki position (the taumu'a 'olovaha or 'head of the kava bowl') at kava ceremonies.

It should also be noted that the positions of tauhifonua and matapule were sometimes awarded to people of high standing or exalted deed. As Gifford noted:

A warrior who killed ten men and brought the heads as evidence was highly regarded and might be raised to the rank of a matapule or a petty chief ('eiki si'i) and be given land; or again he might be given the privilege of drinking his chief's kava when it was called. (Gifford 1929: 126) ${ }^{19}$

Ironically, while the matapule still perform their ceremonial roles in contemporary Tonga, the position of tauhifonua does not exist in the formal sense. The position was not recognised in the Tongan Constitution introduced in 1875 by King Taufa'ahau Tupou I. While the guardian of the fonua thus lacks a role in the modern Tongan State, high ritual and ceremonial occasions often do reactivate older social roles such as the tauhifonua.

During my fieldwork period, I discovered that one of my informants was in fact a tauhifonua and continued to perform roles associated with the title, such as taking the chiefly role of taumu'a 'olovaha, 'head of the kava bowl', at most kava ceremonies in the village. This role became even more prominent with the death of the noble of the village, as my informant received tribute and other ceremonial honours during the mourning period observed by the village (and the nation) in respect of the deceased noble.

Former tauhifonua were 'honoured' during the reign of Queen Salote (1918-65) when she appointed many of them as 'ofisi kolo, 'town officers', and 'ofisi vahefonua, 'district officers'. 'Ofisi kolo and 'ofisi vahefonua today represent 'the hereditary estate holder in day-to-day affairs of the village [making] recommendations about allocation of farming and town allotments' (Wood-Ellem 1999: xv). These officers of the contemporary State perform roles that reflect the function but not the content of their former social and ritual status as tauhifonua.

\section{Fonua and Agricultural Production}

While social and ritual roles were key tasks performed by the tauhifonua, there was also an important economic imperative associated with the fonua of a titleholder. Agricultural production on and by the fonua formed an important component of the hierarchical social and political system of pre-constitution Tonga. Under the guidance and orders of the tauhifonua, who was in turn 
following the directions of the chiefly titleholder, the 'ulumotu'a of a fonua directed the production and distribution of agricultural produce of the fa' ahinga (and associated 'api 'homestead') under his auspices.

While subsistence farming was of course an important focus of 'api activities, chiefs also required the production of a surplus in order to fulfil ritual and tributary obligations to higher-ranking chiefs including the Tu'i Tonga. The most famous example of this form of obligation was the 'inasi, 'first fruits', ceremony, an annual tribute of yams ('ufi) to the Tu'i Tonga by the chiefs of all of Tonga. Of course, it was the 'commoners' $(t u$ ' $a$ ) working on the 'api plantations who actually cultivated and harvested the produce by order of their chiefs. Captain Cook (1777), William Mariner (1817) and Rev. John Thomas (1879) all described the 'inasi ceremonies as the distribution of a portion of the produce of the land 'to ensure the protection of the gods, that their favour may be extended to the welfare of the nation generally, and in particular to the productions of the earth, of which yams [were] the most important' (Mariner 1827, No. 162: 342). ${ }^{20}$ It should be noted that while yams were the focus of the ceremony, other gifts designated as 'valued goods' (koloa), such as fine mats, were also included as tribute. Thus the 'inasi served as a harvest prayer to the gods and as a staged demonstration on the part of the elites of their sacred and secular powers. In summary, the fonua was an integral component of the Tongan State.

\section{Fonua in Contemporary Tonga}

This is tradition constructed in the present, however, not one that is glued to the past. (Flinn 1992: 45)

\section{Constitutional Changes and the Individualisation of Land Tenure}

Having outlined the localised practice of fonua in the pre-constitution period, the focus moves to fonua as it is utilised within the framework of contemporary national discourse. While today the concept still denotes place and people, the contexts in which the category is employed have changed. The primary changes relate to the fact that in post-constitution Tonga, fonua has been separated from the geographical context of local territory, the economic context of agricultural production and the social context of ritual obligation. Fonua has now become a symbol of national identity.

This transformation coincided with fundamental societal changes which occurred in Tonga during the 19th century. Codified in the 1875 Constitution, these changes included the unification of all the islands of the archipelago under one chiefly family and the installation of the contemporary monarchy; the abandonment of the ancient religion and adoption of Christianity; the dismantling 
of the chiefly system and the creation of a class of nobles; and the introduction of new land tenure arrangements.

While incorporating some elements of the fonua system, the new laws radically shifted emphasis away from a local communal organisation of production towards individual household production. Morton termed this individualising tendency of the new laws 'atomisation' (Morton 1987). While ensuring that all land in Tonga remained inalienable with ultimate title belonging to the King, the land was divided into 'estates' (tofi'a) controlled by a new class of 36 noble landholders. Nobles were allocated more than one tract of land, with most tofi'a incorporating numerous tracts of land on different islands. In most cases, individual holdings within these 'estates' conform to original fonua boundaries. The land encompassed within the tofi'a estates was then subdivided so that every male Tongan aged 16 years and over could access land. Two forms of landholding were designated: the 'api uta or 'bush or plantation allotment', which incorporated eight and a quarter acres of agricultural land, and a 'api kolo or 'tax/town allotment' on which to build a house (Maude 1971). Nobles were granted responsibility for the distribution of land on their tofi' $a$ estate and, more importantly, discretion over title succession for heirs to town and bush allotments on the death of the landholder. Many nobles use these rights to their capital advantage in modern Tonga.

These land tenure changes, combined with the political and social upheavals of the 19th century, resulted in significant changes to the structure of social organisation and the focus of economic production. Although slow to be adopted (James 1995), the new land tenure arrangements had a profound effect on the fonua system. Individual landholding and production led to the demise of communal production directed by the 'ulumotua and the tauhifonua on behalf of the titleholder. The position of tauhifonua was abolished, or, more correctly, was not recognised under the new system. The demise of homesteading as the primary settlement pattern also accelerated as commoners coalesced in villages, building houses on their 'api kolo town allotments and growing crops for their fāmili and kāinga on their individually owned 'api uta bush allotments. ${ }^{21}$

Needless to say, these changes profoundly altered the context in which fonua was utilised. A primary signifier of this change was the replacement of fonua with the concept of tofi'a ('estates') to denote a landholding. This transformation symbolically separated the people from the context of land. Tofi'a or 'estate' emphasises the connection between the noble and his land rather than the symbolic stress on a kinship connection between the chiefly titleholder, the guardian of place, and the people in the place (Evans 1996: 62) embodied in the notion of fonua. 


\section{Fonua and Contemporary National Identity}

'The Tongan way' (anga fakatonga) is frequently invoked in everyday life in Tonga as both the defining element of Tongan identity and as the values and behaviours that comprise Tongan culture. Anga fakatonga is also rendered as 'ulungaanga o e fonua or anga fakafonua: the way of the land and the people. (Morton 1996: 20)

Detached from the pre-constitution societal framework of communal production and direct connection to a titleholding hierarchy, fonua is today most often employed in a national political context. While transforming the circumstances in which the concept of fonua is invoked from the local to the national, the category continues to emphasise the connection between the Tongan people and Tonga as place.

During fieldwork, a recurring subject for discussion by my informants was a comparison between Western societies and Tonga. This was not particularly surprising given that a major focus of my work is movement and migration and that a significant proportion of the population now live and work in countries outside Tonga. In most cases, these discussions focused on a comparison of values. The positive value of anga faka-Tonga, 'the Tongan way', was contrasted with negative values attributed to Western societies. These negative values included the importance of a secular lifestyle above a spiritual relationship with God, and the privileging of money and work above family.

The positive value of anga faka-Tonga, 'the Tongan way', was emphasised continually as an integral and necessary component of adult Tongan behaviour. This concept is an embodiment of core Tongan values and consists of duty (fatongia) incorporating responsibility towards the fulfilment of kinship obligation, expressed symbolically through 'ofa, 'love', and faka'apa'apa, 'respect'.

In contrasting positive Tongan values with negative Western values, my informants used the word fonua to denote the positive connection between the place and people of Tonga. Fonua would be invoked in phrases such as 'Ko $e$ fonua a'aku eni', which translates approximately as 'This place/people [Tonga/Tongans] are my land/people' or 'I am a component of this place/people known as Tonga.' These connections, made in the context of anga faka-Tonga, 'the Tongan way', are also embodied in the phrase 'kainga kakaifonua', denoting 'the community/family group of the people of the nation of Tonga'. This statement incorporates the Tongan people as a unified, extended community/family. Fonua has therefore become the embodiment of a historicised national identity.

The importance of this symbolic utilisation of fonua is particularly significant given the establishment of numerous Tongan communities in the countries of 
the Pacific Rim. With second- and third-generation Tongans being raised in Western countries, issues of identity have become extremely salient for Tongans at home and abroad. As a result, fonua has come to embody values held as being core to Tongan identity, as well as representing a connection between the Tongan people (wherever they might be in the world) and the physical place of Tonga itself (both the nation of Tonga and the villages/islands/clusters from which individuals claim origin).

\section{Fonua as Home}

The irony of these times, however, is that as actual places and localities become ever more blurred and indeterminate, ideas of culturally and ethnically distinct places become perhaps even more salient. It is here that it becomes most visible how imagined communities (Anderson 1983) come to be attached to imagined places, as displaced peoples cluster around remembered or imagined homelands, places or communities in a world that seems increasingly to deny such firm territorialised anchors in their actuality. (Gupta and Ferguson 1997: 10-11)

The mythological, historical and contemporary conceptions of fonua, 'people of/and place', explored in this paper incorporate mythic and locally connected aspects of 'home' as identified by Brah (1996).

In the first instance, Brah identifies home as a 'mythic place of desire in the diasporic imagination' (Brah 1996: 192). Fonua corresponds with this description when Tongans invoke the word as a signifier of identity, belonging and unity (of people and of place). The incorporation of fonua in the mythological storytelling of the past and the contemporary assertion of fonua as a representation of national identity are two examples of fonua in mythic mode. Fonua claimed in this way is a statement of connection (mutually understood), which all Tongans might make, whether they live in Tonga or in some other place, whether they were born in Tonga or in some other place. Through its association with the powerful declaration of Tongan cultural distinctiveness, anga fakaTonga, 'the Tongan way', fonua in this sense supports notions of belonging and unity among Tongans, wherever they are and whoever they are.

Through bonding fonua, the 'people and place', with anga fakaTonga, 'the Tongan way', in the contemporary context, Tongans place their national self-identification in contradistinction to an imagined set of palangi, 'Western', values and beliefs. In everyday discourse, Tongans define this contrast as a distinction between fonua (Tongan place and Tongan people) and muli (foreign places populated by foreign people and Tongans).

On the other hand, fonua is also grounded (literally) in the actuality of place and territory, hence fonua as the 'the lived experience of a locality. Its sounds and smells, its heat and dust' (Brah 1996: 192). Fonua invoked as local belonging 
intimately associates people with the place/s of their birth, childhood and journey to adulthood. These local places include the remembered chief-associated territory (fonua) and kinship ('api/kainga) groupings of local districts, the contemporary invitation to land use represented by the toutu' $u$ and the shared histories and connections associated with villages, islands and island clusters ('otu motu).

In mythic mode, fonua may be seen to represent home as a unified, shared understanding that connects all Tongan people. In local mode, fonua invokes home as a local association, an association that privileges the few rather than the whole, exclusive in a sense to the individual. When examined from this perspective, fonua recalls the principles of separation and connection invoked in the Poem of Tuku'aho discussed above - separation in that both dimensions of fonua-as-home serve to distinguish Tongans from non-Tongans (the mythic) and individual Tongans from each other (the local). Connection in that the mythic and local dimensions of fonua connect Tongans in historical, cultural, economic and imaginary associations. Fonua therefore represents a powerful social construction, accommodating assertions of national unity (one people, one place) and a celebration of the diverse histories and distinct territories (many people, many places) that today comprise the Kingdom of Tonga.

\section{References}

Campbell, I. 1992. Island Kingdom: Tonga Ancient and Modern. Christchurch:

Canterbury University Press.

Beaglehole, J.C. 1967. The Journals of Captain James Cook on his Voyages of Discovery.

Cambridge: The Hakluyt Society.

Blust, R. 1980. 'Austronesian Etymologies.' Oceanic Linguistics, 19. pp. 1-189.

Bonnemaison, J. 1994. The Tree and the Canoe: History and Ethnogeography of Tanna.

Honolulu: University of Hawai'i Press.

Bott, E. 1982. Tongan Society at the Time of Captain Cook's Visits: Discussions with Her Majesty Queen Salote Tupou. Vol. 44. Wellington: The Polynesian Society.

Brah, A. 1996. Cartographies of Diaspora: Contesting Identities. London: Routledge.

Collocott, E.E.V. 1928. 'Tales and Poems of Tonga.' Bernice P. Bishop Museum Bulletin, Vol. 46. Honolulu: Bernice P. Bishop Museum.

Cummins, H.G. 1977. 'Tongan Society at the Time of European Contact.' In N. Rutherford (ed.), Friendly Islands: A History of Tonga, Oxford: Oxford University Press. pp. 63-89. 
Davidson, J.M. 1977. 'Western Polynesia and Fiji: Prehistoric Contact, Diffusion and Differentiation in Adjacent Archipelagos.' World Archaeology, 9. pp. 83-94.

Dickinson, W.R., R. Shutler, R. Shortland, D.V. Burley, and T. Dye. 1996. 'Sand Tempers in Indigenous Lapita and Lapitoid Polynesian Plainware and Imported Protohistoric Fijian Pottery of Ha'apai (Tonga) and the Question of Lapita Tradeware.' Archaeology in Oceania, 31. pp. 87-98.

Evans, M. 1996. 'Gifts and Commodities on a Tongan Atoll: Understanding Intention and Action in a MIRAB Economy.' McMaster University, Ontario. unpublished $\mathrm{PhD}$ thesis.

Finney, B. 1997. 'Tongan Society at the Time of European Contact.' In N. Rutherford (ed.), Friendly Islands: A History of Tonga, Oxford: Oxford University Press. pp. 63-89.

Flinn, J. 1992. Diplomas and Thatch Houses: Asserting Tradition in a Changing Micronesia.

Ann Arbor: the University of Michigan Press.

Gailey, C.W. 1987. 'Kinship to Kingship: Gender Hierarchy and State Formation in the Tongan Islands.' Texas Press Sourcebooks in Anthropology, Vol. 14. Austin: University of Texas Press.

Gifford, E.W. 1924. 'Tongan Myths and Tales.' Bernice P. Bishop Museum Bulletin, Vol. 8. Honolulu: Bernice P. Bishop Museum.

Gifford, E.W. 1929. 'Tongan Society.' Bernice P. Bishop Museum Bulletin, Vol. 61: Bayard Dominick Expedition Publications. Honolulu: Bernice P. Bishop Museum.

Goodenough, W.H. and S.D. Thomas. 1989. 'Traditional Navigation in the Western Pacific: A Search for a Pattern.' Expedition. 29. pp. 3-14.

Gordon, T. 1988. 'Inventing Mormon Identity in Tonga.' Unpublished PhD thesis University of California.

Green, R.C. and P.V. Kirch. 1997. 'Lapita Exchange Systems and their Polynesian Transformations: Seeking Explanatory Models.' In M.I. Weisler (ed.), Prehistoric Long-Distance Interaction in Oceania: An Interdisciplinary Approach, Monograph 21, Auckland: New Zealand Archaeological Association. pp. 19-37.

Grijp, P.v.d. 1993. Islanders of the South: Production, Kinship and Ideology in the Polynesian Kingdom of Tonga. Leiden: KITLV Press.

Gupta, A. and J. Ferguson. 1997. 'Beyond "Culture": Space, Identity, and the Politics of Difference.' In A. Gupta and J. Ferguson (eds), Culture, Power, 
Place: Explorations in Critical Anthropology, New York: Duke University Press. pp. 6-24.

Herda, P.S. 1988. 'The Transformation of the Traditional Tongan Polity: A Genealogical Consideration of Tonga's Past.' Unpublished PhD thesis. The Australian National University, Canberra.

James, K. 1995. 'Right and Privilege in Tongan Land Tenure.' In R.J. Ward and E. Kingdon (eds), Land, Custom and Tenure in the South Pacific, Cambridge: Cambridge University Press. pp. 157-89.

La Perouse, J. 1779. A Voyage Round the World Performed in the Years 1785, 1786, 1787 and 1788 by the Boussole and Astrolabe. New York: Da Capo Press.

Kaeppler, A.L. 1978. 'Exchange Patterns in Goods and Spouses: Fiji, Tonga and Samoa.' Mankind, 11. pp. 246-52.

Kaeppler, A. 1993. Poetry in Motion: Studies of Tongan Dance. Nuku'alofa: Vava'u Press.

Mahina, O. 1992. 'The Tongan Traditional History Tala-e-Fonua: A Vernacular Ecology-Centred Historico-Cultural Concept.' Unpublished PhD thesis. The Australian National University, Canberra.

Marcus, G.E. 1975. 'Alternative Structures and the Limits of Hierarchy in the Modern

Kingdom of Tonga.' Bijdragen de Tot-Taal-en Volkenkunde, 131. pp. 34-66.

Mariner, W. 1827. An Account of the Natives of the Tonga Islands in the South Pacific. Compiled and arranged by John Martin. Nuku'alofa: Vava'u Press.

Maude, A. 1965. 'Population, Land and Livelihood in Tonga.' Unpublished PhD thesis. The Australian National University, Canberra.

Maude, A. 1971. 'Tonga: Equality Overtaking Privilege"' In R. Crocombe (ed.), Land Tenure in the Pacific, London: Oxford University Press. pp. 10628.

Morton, H. 1996. Becoming Tongan: An Ethnography of Childhood. Honolulu: University of Hawai'i Press.

Morton, K. 1987. 'The Atomisation of Tongan Society.' Pacific Studies, 10. pp. 47-73.

Pawley, A. and M. Ross. 1993. 'Austronesian Historical Linguistics and Culture History.' Annual Review of Anthropology, 22. pp. 425-59.

Reiter, P. 1907. 'Traditions Tonguiennes: De l'Origine de Diables ou Dieux.' Anthropos, 2. pp. 230-40, 438-48, 743-54. 
Weisler, M.I. and J.D. Woodhead. 1995. 'Basalt Pb Isotype Analysis and the Prehistoric Settlement of Polynesia.' Proceedings of the National Academy of Sciences, 92. pp. 1881-5.

\section{Wood-Ellem, E. 1999. Queen Salote of Tonga: The Story of an Era 1900-1965. Auckland: Auckland University Press.}

\section{ENDNOTES}

1 The use of the term fanua, the older form of fonua, was recorded by Evans (1996) on the island of Ha'ano (in the Ha'apai cluster) and during my fieldwork the term was sometimes utilised by people from the island of Foa (also in the Ha'apai cluster).

2 This fonua territory also incorporated the sea.

3 These dates were derived from charcoal samples taken at six sites in Ha'apai containing eastern Lapita and Polynesian plainware pottery.

$4 \mathrm{PN}$ is an abbreviation of Polynesian.

a In the translation, Kaeppler glosses fonua as 'land', however, I have replaced it with the gloss 'people/place' in order to maintain consistency of meaning in the context of this paper.

b This extract is taken from Kaeppler (1993: 64-5).

5 The poetic technique of heliaki, 'ironic discourse/double meaning', which is utilised extensively in Tongan poetry and dance, is also employed in the Lau Langi. For example, the use of the word 'unga in the dance evokes for Tongans a multiplicity of mental associations including images of decay, rotting coconuts and the holes made by worms and grubs.

6 This phrase is most commonly glossed as the 'earth eaters'.

7 It is important to note that the paragraph breaks have been inserted to facilitate my discussion of the myth later in this section. Normally the story is presented as a complete block.

8 These beings represent the three principal gods of the old Tongan religion.

9 This version of the talatupu'a is a rendering based on a combination of accounts presented by a number of authors (Gifford 1924; Herda 1988; Mahina 1992; Reiter 1907).

10 It is important to note that the term talatupu'a is also used to describe the telling of any 'ancient' Tongan myth.

11 As Gunson (1993) has pointed out, received versions of the myth have been modified over the years to highlight and illuminate the divine origin of certain descent lines, particularly the current monarchy. As myth and legend have for centuries often been tools utilised by the elites, this practice is neither new nor surprising.

a This is an excerpt from the Poem of Tuku'aho (Collocott 1928: 95) written in the early 1800s by Teukava, a chief of Hihifo, Tongatapu, who was an ally of the famous Ha'apai chief, Finau Ulukalala II, whose exploits were documented by the shipwrecked seaman William Mariner in his Account of the Natives of the Tonga Islands in the South Pacific.

12 'Uta connotes land without people and is often glossed as 'bush'. In this way, it can be distinguished from fonua, 'people of/and place'.

13 Tangaloa 'Eitumatapua was a brother of Tangaloa 'Atulongolongo and son of Tangaloa 'Eiki and Tamapo'uli.

14 In the literature, fa'ahinga is sometimes substituted with the term matakali (see Kaeppler 1971, for example). Matakali appears to have been derived from the Fijian mataqali. It should also be noted that neither of these kinship categories continue to be employed in the contemporary context.

15 After the effective demise of the fa'ahinga/matakali (as noted above), the 'ulumotu'a continues to play a minor role within Tongan families today as the coordinator of kāinga-(see above) focused activities for life-stage events.

16 The maapule performed the role of attendant and spokesman for the 'eiki, 'chief'.

17 Kainga is an ancient kinship category that designates a unit larger than fāmili, covering an extended bilateral descent group in a cognatic network. Kainga has sometimes been described as an ideal ego-centred kindred' (Evans 1996: 110). 


\section{Sharing the Earth, Dividing the Land}

18 It is difficult to estimate the number of fonua that existed in Tonga as they waxed and waned over time (a few hundred at the most). Estimating the number of people contained within a fonua is also difficult, although fonua could reasonably have incorporated at least 50 people, although more likely hundreds as whole villages could be subsumed within a fonua.

19 'Petty chief' is Gifford's phrase for the tauhifonua position.

20 There is some conjecture about whether the ceremony that Cook witnessed was truly the 'inasi ceremony or some other sacred event such as a Tu'i Tonga installation ceremony relating to power plays at the time. Also Thomas (1879) refers to two 'inasi ceremonies, one in June and another in October (Beaglehole 1967: 145; Campbell 1992; Cummins 1977; Herda 1987).

21 A Tongan translation of the English word family, famili, is a flexible modern concept that primarily denotes parents and their children, but also encompasses any extra lineal and collateral kin from several genealogical levels living on an 'api kolo or 'town allotment'. 